\title{
Integrating Drone Technology in Service Learning for Engineering Students
}

\author{
https://doi.org/10.3991/ijet.v16i15.23673 \\ Fatin Aliah Phang $\left.{ }^{1}{ }^{凶}\right)$, Jaysuman Pusppanathan ${ }^{1}$, Nina Diana Nawi ${ }^{1}$, \\ Nur Amira Zulkifli ${ }^{1}$, Izwyn Zulkapri ${ }^{1}$, Fauzan Khairi Che Harun ${ }^{1}$, \\ Adam Wong Yoon Khang ${ }^{2}$, Jamil Abedalrahim Jamil Alsayaydeh ${ }^{2}$, Tee Kian Sek \\ ${ }^{1}$ Universiti Teknologi Malaysia, Johor, Malaysia \\ ${ }^{2}$ Universiti Teknikal Malaysia Melaka, Malacca, Malaysia \\ ${ }^{3}$ Universiti Tun Hussein Onn Malaysia, Johor, Malaysia \\ p-fatin@utm.my
}

\begin{abstract}
Future engineers shall not only good at knowledge and technology but also good at other attributes such ethical, professional as well as managing people and emotion. Service learning is an effective education model to develop more holistic engineers. However, there is a lack of service learning frame- work that integrates technology, in order to achieve the acquisition of the above attributes. This paper describes how drone technology is disseminated by engineering students to the public through a service learning programme. Document analysis of the course information, project reports, and students' reflections were employed in this study to identify the learning process and attributes developed by the students. the students went through 6 phases of service learning implementation. Results show that the service learning has enhanced the students' learning, sense of responsibility, accountability, and international exposure. These are essential to develop good engineers in the future.
\end{abstract}

Keywords-drone, drone technology, service learning, engineering education

\section{Introduction}

As Fourth Industrial Revolution (4IR) approaches, Higher Education Institutions (HEIs) must change in order to produce graduates that exhibit competencies beyond discipline-specific knowledge [1]. Therefore, HEIs should reinvent by shifting the focus from teaching to learning and from assessment of knowledge to assessment of skills [2]. According to Phang et al. [3], conventional teaching approach should be reviewed and improvised for a country to stay competitive in the era of 4IR. Malaysia as a developing country must continue to transform its education.

Recently, a number of research [5-7] have been conducted locally and globally to improve the quality and provision of higher education. This is in accordance with the advent of the 4IR that pushes HEIs to promote self-directed, independent learning and 21 st century competencies skills [7]. World Economic Forum [8] listed the top 15 skills for future jobs in 2025 which are: analytical thinking and innovation; active learning 
and learning strategies; complex problem-solving; critical thinking and analysis; creativity, originality and initiative; leadership and social influence; technology use, monitoring and control; technology design and programming; resilience, stress tolerance and flexibility; reasoning, problem-solving and ideation; emotional intelligence; troubleshooting and user experience; service orientation; systems analysis and evaluation; and persuasion and negotiation. Zooming in the engineering professions [9], the aforementioned skill set is more important now than before.

The transition as engineering students to practicing engineers is a complex process

[10] especially in terms of communication skills, responsibility and self-confidence among the students. This could be countered by adding 'cross-cultural' adjustment into the courses [11]. This is also in agreement with the study of Tan [12] on the expectations gap for engineering field in Malaysia in the 21st century. The setting of today's labour market is becoming competitive to meet the globalization of all industry. Engi neering employability skills are therefore necessary for Malaysian industries to remain competitive [13].

Human Resources Development Fund [14] reported that Malaysia is facing a shortage in the labour market due to insufficient supply of workers with significant skills to meet the demand. This is also contributed by the constant changing demand for partic ular set of skills on technologies, digitization, automation, and other related to IR4.0. It is reported that the skills shortage is due to the misalignment of the education system with labour market and under developed adult education and training system [15]. However, it is argued that it is not sensible [16], if the educational setting were designed solely towards the training system for graduate's employability. Based on the empirical and conceptual studies, educational setting should go beyond employability by fostering human capabilities, especially in the generic skills that are highly sought after in all professions [8].

The obvious gap, mismatch [17] and silo mentality among the HEIs and employers in Malaysia have pressured the HEIs to adopt a different pedagogical method [18], utilizing educational technology tools as a platform to aid in the process of information transmission based on updated graduate attributes across all stakeholders [19-21]. It is established that teaching pedagogy via service learning has positive impacts on students, community and industry. Research [22-23] indicates that service learning is among the most pertinent pedagogical approach to instill the graduate's employability and capabilities [16]. Through service learning, it helps students gain knowledge, skills and other attribute as listed by WEF [8]. In the era of 4IR, service learning should be integrated with emerging technologies, however, there is limited-service learning that engages with the particular set of skills on technologies and digitization, and there is a lack of theoretical framework to conduct service learning with the integration of these emerging technologies. This paper seeks to propose a framework to integrate emerging technologies in engineering service learning with international engagement. 


\section{$2 \quad$ Literature review}

Service learning is a pedagogy with designated process by a facilitator for learners to construct their learning experience. This learning pedagogy grounded [24] by the active nature of understanding and the benefits of participatory democracy which students cooperatively engage in actual social problems as exacted by John Dewey. Benjamin Franklin also reinforced the precursors with his belief; 'Tell me and I forget. Teach me and I may remember. Involve me and I will learn'. Through service learning, it gives direct and immediate benefits [25] to anyone engage in the projects whether they are students, community and industry.

Extensive studies [29-31] showed that through service learning, students learn critical skills in communicating, participating in sustainability efforts and applying the distinctive skills during the course to effect change. To this end, service learning has become a bridge for students to understand the key components and learning tools used in the class, ultimately applying them in the real-world setting. Engineering educators play a highly significant task in guiding, supervising, and designing the teaching and learning environment for the engineering students. Singh [29] pleaded educators to develop an innovative teaching pedagogical that will cultivate the social responsibility and interest for the public. Inductive instruction and effective assessment on the students' ability are the important elements to bridge the gap between classroom teaching and the engineering profession $[1,30]$. Therefore, service learning is a combination of academic content and teaching, service experience and reflection [27] as shown in Fig. 1.

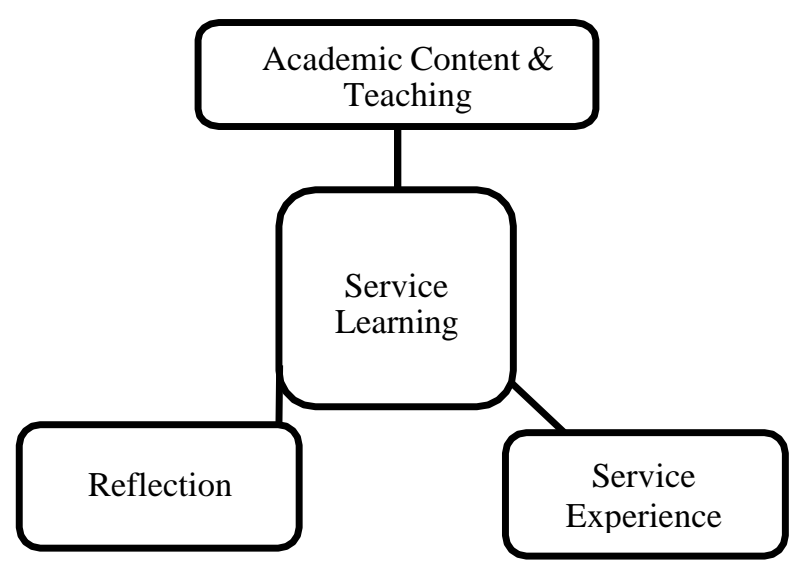

Fig 1. Basic Components of Service Learning [27]

The integration of service learning with digital technologies [22] can be achieved through thoughtfully designed and implemented teaching pedagogies. It is vital to keep the distinctive strengths of each and intentionally merging them in accordance with clear articulation of learning goals. The digital technology through thoughtful design of service learning can broaden, deepen, and integrate civic and humanistic outcomes in learners' developmental pathways, and promoters of changes that will foster equity 
and justice. Service learning that is incorporated with new insights on digital technology certainly goes beyond normal setting. As for the international context, global engineer attributes [32-34] could become a guide to design the service learning. Among the global attributes are the capability of speaking two languages, can adapt to new situation, have global perspective, and others.

Undeniably, service learning [19] has become an established pedagogy that guarantees the experiential learning exist in the HEIs. In this paper, service learning implementation using technology and digitization was explored to investigate its ability to empower engineering students by organizing a Service Learning project that encompasses Science, Technology, Engineering and Mathematics (STEM) educational programme named "Drone Tech for 4IR". This study attempts to present the service learning by using Drone as the academic content.

\section{$3 \quad$ Service Learning Design}

Drone Technology is a new co-curriculum course introduced by Universiti Teknologi Malaysia (UTM). It is also a part of the Service Learning Malaysia University for Society (SULAM) to promote Love, Happiness and Appreciation. The course was carried out over the span of 14 weeks which is equivalent to 80 hours of Student Learning Time (SLT) throughout one semester. A part of the assessment of this course entailed continuous assessment on the graduate attributes of global citizen, knowledge, scholarship, adaptability, leadership and team working skills. Each class session was scheduled for 2 hours of face-to-face meeting, with extra online learnings, hands-on practice and laboratory work as shown in Table 1 . The service learning project on "Drone Tech for Edu-IR" was proposed, planned and implemented by 31 students dur ing the semester 1,2019/2020 session.

The weekly schedule was divided into three components of service learning as in Fig. 1 [27]. In the first three weeks, the facilitators introduced the IR4.0, drone technology and the significant of service learning project to meet with the competitive global environment [4]. The facilitators guided the students to appoint the service learning project committee and to form task groups. The students planned and strategized on how to carry out the service learning for the community at the end of the semester. This was carried out with the students through lectures and active learning via real world setting.

In the following weeks, the students visited the laboratory for hands-on activities such as assembling drones, flight practice on simulator software and basic troubleshooting tasks. By the end of week seven, the students obtained adequate knowledge and experience to further plan for their service learning project. Since this course assesses team working skills, the facilitators employed five principles of cooperative learning [3] of positive interdependence, individual accountability, face to face interaction, appropriate interpersonal skills and group function assessment in this course. Each group members had different role to complete the project and each group was responsible for different tasks given. They must work together and help each other to ensure the success of the project. 
The crucial element in this particular service learning project is for the group to prepare a proposal for service learning. This included tasks such as negotiating with local community to collaborate on the project, seeking sponsors and financial aid, planning for the technical content of the service learning project and finally to execute the project with the stakeholders (local community). Upon completion of the event (service learning), the students were required to make reflection about their experience gained throughout the whole duration of this project. The facilitators guided them with occasional advice, assistance, and correction while allowing them to explore independently as well as interacting among their group members. The facilitators played an essential role to challenge and guide the students in exploring the service learning modus operandi.

Table 1. Course design

\begin{tabular}{|c|c|}
\hline Week & Week Content \\
\hline \multicolumn{2}{|r|}{ Academic Content and Teaching } \\
\hline 1 & $\begin{array}{l}\text { - Introduction to Industry 4.0 Revolution \& Drone Technology } \\
\text { - Introduction to service learning project }\end{array}$ \\
\hline 2 & $\begin{array}{l}\text { - Flight rules \& safety of drones } \\
\text { - Service learning project planning }\end{array}$ \\
\hline 3 & $\begin{array}{l}\text { - Components, software and drone programs } \\
\text { - Project Implementation Setup. }\end{array}$ \\
\hline \multicolumn{2}{|r|}{ Service Learning Experience } \\
\hline $4-7$ & $\begin{array}{l}\text { - Drone construction, installation and testing } \\
\text { - Group discussion } \\
\text { - Preparation of a service learning project proposal } \\
\text { - Sponsored search } \\
\end{array}$ \\
\hline $8-10$ & $\begin{array}{l}\text { - Operation \& simulation of drone flights } \\
\text { - Presentation of Recommendation Paper for Service learning project }\end{array}$ \\
\hline $11-13$ & $\begin{array}{l}\text { - Project Implementation Setup } \\
\text { - Implementation of service learning project } \\
\text { - Report Preparation }\end{array}$ \\
\hline \multicolumn{2}{|r|}{ Service Learning Reflection } \\
\hline 14 & - Presentation of Project Results \\
\hline & $\begin{array}{l}\bullet \text { Report Submission } \\
\bullet \text { Assessment and reflection Service learning project }\end{array}$ \\
\hline
\end{tabular}

"Drone Tech for Edu-4IR" is the service learning project proposed by the students during the fifth week of the course. The proposed project underwent a few revisions to ensure the event could achieve the objectives of service learning. Based on the report, the group created a partnership with Fit Tix Sdn Bhd and Iskandar Investments Bhd to raise awareness of current technological development, especially the potential of drones for the future. The objectives of this project were to transfer knowledge from students to the community on the descriptions and demonstrations of drone racing leagues, drone specifications, and many other important aspects related to drones, to 
the public. The one-day event comprised of three sub-events; a drone workshop, a drone seminar and an international drone competition. The three sub-events were managed by the students in three working groups formed during the first three weeks of the semester. The facilitators observed the students and provided assistance whenever necessary especially matters related to the safety of the students and the participants. A total of 200 school pupils ("pupils" is used for school students while "students" refers to the university students who took the service learning course) from age 10 to 16 years old took part in the event. The university students went through 6 phases as shown in Table 2 to successfully executed the "Drone Tech for Edu-4IR" service learning project.

Table 2. Course implementation

\begin{tabular}{|l|l|}
\hline \multicolumn{1}{|c|}{ Phase } & \multicolumn{1}{c|}{ Description } \\
\hline SL Objectives Exposure & $\begin{array}{l}\text { Students were briefed on the service learning objectives learning need to be } \\
\text { achieved. }\end{array}$ \\
\hline SL Team Construction & $\begin{array}{l}\text { Students designed to build effective teams to achieve the main objectives of ser- } \\
\text { vice learning. Facilitators play role as guide by } \\
\text { side. }\end{array}$ \\
\hline SL Planning and analysis & $\begin{array}{l}\text { Meetings conducted to discuss, plan and analyse the location, potential stakehold- } \\
\text { the facilitators as meddler in } \\
\text { the middle. }\end{array}$ \\
\hline SL Design Development & $\begin{array}{l}\text { Based on the previous step, students designed and improved the designated ser- } \\
\text { vice learning programme to meet the objectives. }\end{array}$ \\
\hline SL Execution & $\begin{array}{l}\text { A briefing session before executed the programme. Students worked in their re- } \\
\text { spective teams to achieve respective objectives. }\end{array}$ \\
\hline $\begin{array}{l}\text { SL Evaluation and Re- } \\
\text { flection }\end{array}$ & $\begin{array}{l}\text { Students evaluated the performance, effectiveness of the programmes, conduct } \\
\text { reflection to asses themselves and for future } \\
\text { execution of the program. }\end{array}$ \\
\hline
\end{tabular}

The students successfully organized a seminar, workshop and drone racing to achieve the objective of the project as described in the Table 3. The seminar was to introduce the latest drone technology and application as an awareness to public on technology in the era of 4IR. The workshop was for the public to experience flying drones themselves either in the simulation mode or real flying experience (as in Fig. 2). The public consist of school pupils and parents. Finally, the drone racing competition was participated by 52 pilots from Asian countries (open to youths and adults). This provided the students with the international experience of organizing drone racing competition.

\section{$4 \quad$ Research method}

The service learning implementation and what the students gained were investigated using archival research method. According to Bowen [35], documents analysis will uncover meanings, develop understanding, and discover insights relevant to the research. 
The collected documents for this study are course information and Service Learning Project Report. The report consists of the objectives, work plan, work schedules, minutes of meeting, discussion and students' reflections throughout the course. The documents were analysed based on the implementation and how it had impacted the students and the stakeholders. The data was examined and interpreted in order to elicit meaning, gain understanding, and develop empirical knowledge [36]. Using Miles \& Huberman [37] qualitative data analysis, the data was represented in the following sections.
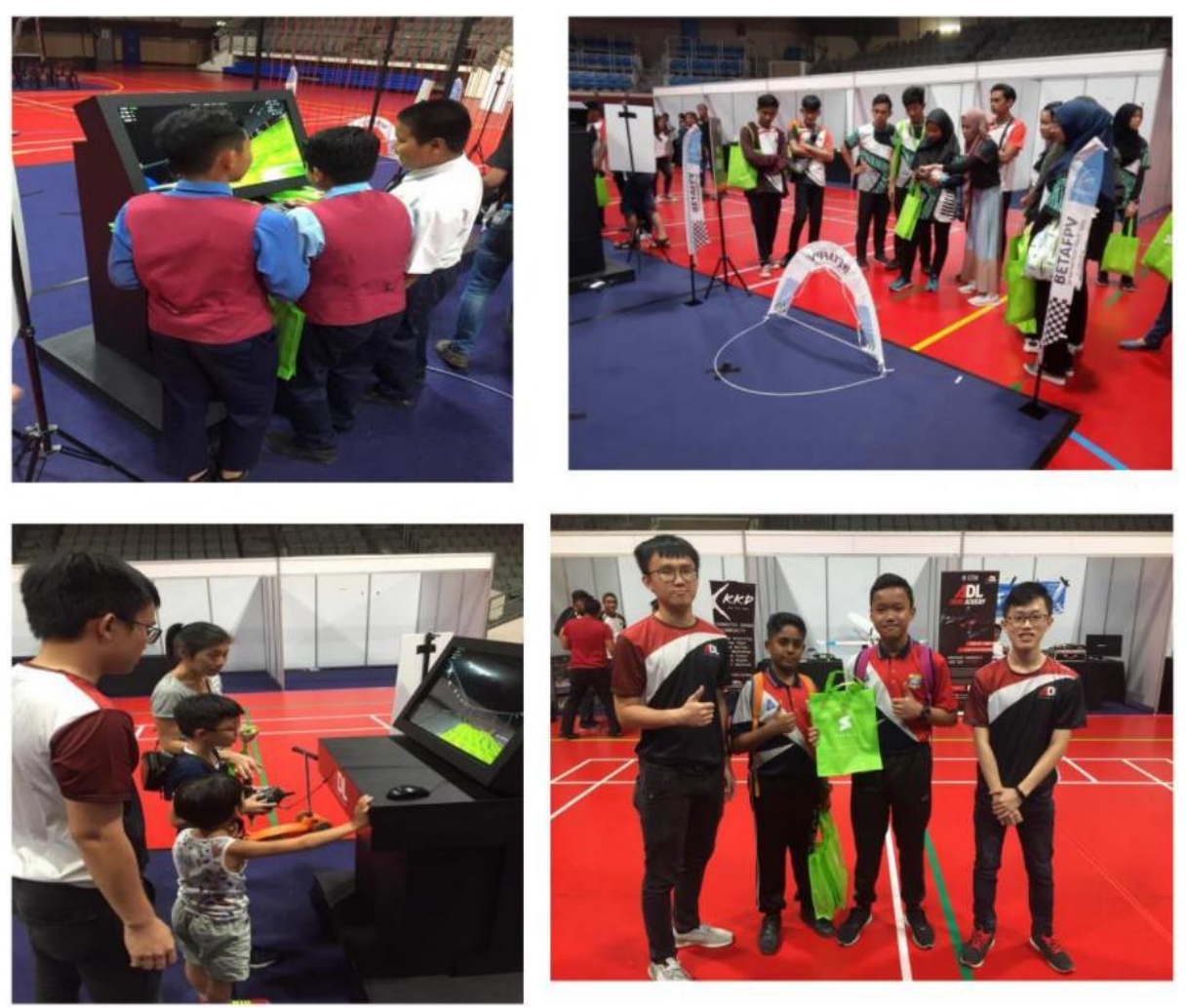

Fig 2. Engineering students interacting with visitors who were enthusiastic to learn about Drone technology at the event

\section{$5 \quad$ Findings and Discussion}

From the qualitative data analysis of the students' report and reflection, it was found that the students actually learned more when they participated in the event they have organized themselves compared to the classes during the course. A student commented:

"On the first day, I met many drone pilots so I could learn much about racing drone from helping them in preparing race arena, etc." - Student T 
The reason for that is because they were able to apply what they have learnt during the event by helping the visitors to the event. A student commented:

Table 3. Students' role in the service learning project

\begin{tabular}{|l|l|}
\hline \multicolumn{1}{|c|}{ Station } & \multicolumn{1}{c|}{ Students Role } \\
\hline $\begin{array}{l}\text { Drone Rac- } \\
\text { ing Station }\end{array}$ & $\begin{array}{l}\bullet \text { Explain to participants about drone base matters. } \\
\bullet \text { Provide participants with exposure to the drone race in person } \\
\end{array}$ \\
$\begin{array}{l}\text { Drone Work- } \\
\text { shop Station }\end{array}$ & $\begin{array}{l}\bullet \text { Reveal to participants about the existence and function of drone flight simulation. } \\
\bullet \text { Opportunities for participants to gain experience in drone management. }\end{array}$ \\
\hline $\begin{array}{l}\text { Drone Semi- } \\
\text { nar Station }\end{array}$ & $\begin{array}{l}\bullet \text { Teach participants the right techniques and ways to fly commercial drones. } \\
\bullet \text { Test the participants' creativity in designing their dream drones. }\end{array}$ \\
\hline
\end{tabular}

"I felt satisfied that the crews [university students] were able to apply the knowledge that they learnt throughout the class and they also able to answer questions that asked by the visitors." - Student $\mathrm{N}$

They felt that the responsibility of sharing their knowledge helps them to learn and also make their own learning more meaningful. A student reported:

"Very meaningful as can let many people understand about drone technol- ogy... Because we have the responsibility to let the community know about drone technology" - Student T

It is only when the students are able to explain the knowledge using their own words that they have truly understand the knowledge. This has reached the highest level of learning based on the Learning Cone of Dale [38]. By changing their belief that the knowledge that they gained would be useful, they will be motivated to learn new knowledge in the future [39].

Other than knowledge, in terms of attributes, they also developed a sense of accountability in them. The event also prompted them to reflect deeper of what they know and do not know. This is good to provide awareness for them to learn more as they know what they should learn and why it is important to learn. A student reflected that:

"We knew the basic knowledge such as categories of drone, price, duration of flying but in term of more technical question such as the difference between two drone of same categories it needs much exposure and exploration." - Stu- dent N

The students also gained experience that is not in the syllabus. A student commented:

"Drone Tech for EDU-4IR allow us to interact with the communities to gain experience that is not in the syllabus. The programmes successfully enhance the confidence and soft skills of leaders in every student"- Student K

Besides learning and accountability, the students also gained some very precious experience of international exposure. A student commented: 
"The best part of the event was international event with many drone racer pilot came from mostly ASEAN countries and there was from Korea too, so it might give us experience to interact with them and learnt their way of conduct (cul- tures)" - Student C

An international service learning can provide much needed exposure for engineers because it is likely for them to work in international scenario with different culture and background. This finding is in accordance with $[7,20]$ on global engineer attributes development [32-34].

The service learning also successfully provided solution for the issues addressed by [10-11] on the lack of communication; responsibility; self-confidence among the graduates through 'cross-cultural' adjustments. The findings from "Drone Tech for Edu4IR" project have proven that service learning is among the most pertinent pedagogical approach [22-23] to unleash the student's potential developing skills according to the top skills listed by WEF [8]. These skills are important for engineers to thrive in the era of 4IR where these skills are not possessed by robots of Artificial Intelligence (AI) yet.

This service learning has successfully provided the students with the content of the course, which is the drone technology; and then with the knowledge, they served the community by organizing a workshop, a seminar and an international drone competition; and finally they were given the chance to reflect on their learning and service experience. This service learning has followed the framework of Muhlestein \& McCann [27] as in Fig. 1. With the guide of a framework, the service learning is able to inculcate the knowledge and skills intended for the students.

Cooperative learning applied in this course has also helped the students to work independently and in a positive manner. They have successfully engaged with the external stakeholders and international community in drone racing. Each students and groups were assigned with different role but to complete the same project. A team of 31 students were able to organize 3 sub-events and entertain 200 school pupils in one day.

Finally, it is worth noting that for a successful implementation of a service learning, beside the framework to guide the course, Table 2 provided a clear guide for other educators who wish to conduct service learning with technologies to ensure that the service learning can be conducted successfully.

\section{Conclusion}

To ensure HEIs produce holistic and quality graduates, it is necessary to redesign the service learning implementation in accordance to the needs of the fourth industrial age and the demand of 21st Century. During the COVID-19 pandemic, it is also important to redesign service learning to e-service learning [40-41] to ensure that this kind of learning can continue. Service learning has successfully inculcated accountability within students and enriching students' learning experience. The framework by Muhlestein \& McCann [27] and the six phases to implement a drone service learning program within an academic course and the stakeholders were proposed. The outcomes of the service learning is encouraging, especially to inculcate 21 st century skills and other important skills for engineers to thrive in their work place. In the future, the proposed service learning process can be the basis for service learning implemen- tation. 


\section{$7 \quad$ Acknowledgement}

The publication is funded by FRGS/1/2019/SSI09/UTM/02/5 and the project is supported by the Universiti Teknologi Malaysia's IIIG Q. J130000.3051.01M70, Q.J130000.3051.01M77, OTR R.J130000.7351.4B391 and GUP Tier 2 Q.J130000.2653.17J29.

\section{References}

[1] P. Nair, "Preparing 21st Century Teachers for Teach Less, Learn More (TLLM) Pedagogies". in Preparing 21st Century Teachers for Teach Less, Learn More (TLLM) Pedagogies P. Kumar, M. J. Keppel, and C.L. Lim, Eds. Malaysia: IGI Global, 2020, pp. 1-9. https://doi.org/10.4018/978-1-7998-1435-1.ch001

[2] P. Ponnudurai, and L. S. Ponniah, "Future Ready Universities: Embracing the 4th Industrial Revolution". in Preparing 21st Century Teachers for Teach Less, Learn More (TLLM) Pedagogies, P. Kumar, M.J. Keppel, and C.L. Lim, Eds. Malaysia: IGI Global, 2020, pp. 54-66. https://doi.org/10.4018/978-1-7998-1435-1.ch004

[3] F. A. Phang, K. M. Yusof, A. A. Aziz, N. D. Nawi, \& A. N. Musa, "Cooperative ProblemBased Learning to Develop 21st Century Skills among Secondary School Students through STEM Education". in 7th World Engineering Education Forum (WEEF), Kuala Lumpur, 2017, pp. 405-409. https://doi.org/10.1109/weef.2017.8467122

[4] M. Ganapathy. "Transformation of Malaysia's Higher Education System: Malaysia Education Blueprint (2015-2025)”, Bulletin of Higher Education Research, National Higher Education Research Institute, pp.10-12

[5] R. G. Bringle and J. A. Hatcher. (2009, September). "Innovative practices in service-learning and curricular engagement”, New Directions for Higher Education. Issue 147, pp. 3746. https://doi.org/10.1002/he.356

[6] A. Kolmos and J. E. Holgaard, "Employability in Engineering Education: Are Engineering Students Ready for Work?" in The Engineering-Business Nexus, S. H. Christensen B. Delahousse, C. Didier, M. Meganck, and M. Murphy, Eds. Springer, 2019, pp. 499-520. https://doi.org/10.1007/978-3-319-99636-3_22

[7] E. Coonan and S. Pratt-Adams, "Building higher education curricula fit for the future", AdvanceHE., Heslington., York, 2018.

[8] World Economic Forum, "The Future of Jobs 2020” WEF., Geneva., Switzerland, 2020.

[9] W. M. Butler, K. Reid, "Introducing Engineering Students to Industry". in AIAA Scitech 2020 Forum, 2020, pp. 1772. https://doi.org/10.2514/6.2020-1772

[10] H. Baytiyeh, and M. Naja, "Identifying the challenging factors in the transition from colleges of engineering to employment". European Journal of Engineering Education, vol 37, issue 1, pp. 3-14, Dec 2011. https://doi.org/10.1080/03043797.2011.644761

[11] E. Kyndt, V. Donche, K. Trigwell, and S. Lindblom-Ylänne, Higher education transitions: theory and research. Routledge, 2017. https://doi.org/10.4324/9781315617367

[12] A. Y. Tan, E. Chew, and V. Kalavally, "The expectations gap for engineering field in Malaysia in the 21 st century". On the Horizon, vol. 25, issue 2, May 2017. https://doi.org/ 10.1108/oth-12-2015-0071

[13] A. Zaharim, M. Yusoff, M.Z. Omar, A. Mohamed, N. Muhamad, and R. Mustapha, "Perceptions and expectation toward engineering graduates by employers: a Malaysian study 
case". WSEAS Transactions on Advances in Engineering Education, vol. 6, issue 9, pp. 296305, Sep 2009.

[14] HRDF Human Capital Report. "Skills Shortage: Malaysian lack of Communication Skills". Issues Sept. 2, 2019.

[15] O. Kupets, "Skill mismatch and overeducation in transition economies". IZA World of Labor(IZA), issue 224, 2015. https://doi.org/10.15185/izawol.224

[16] N. Mtawa, S. Fongwa, and M. Wilson-Strydom, "Enhancing graduate employability attributes and capabilities formation: a service-learning approach". Teaching in Higher Education, pp. 1-17, Oct 2019. https://doi.org/10.1080/13562517.2019.1672150

[17] C. A. Nwajiuba, P. Igwe, A. D. Akinsola-Obatolu, A. Icha-Ituma, and M. O. Binuomote, "A Stakeholder Approach: What can be Done to Improve Higher Education Quality and Graduate Employability?" Industry and Higher Education,vol. 34, issue 5, pp. 358-367, Jan 2020. https://doi.org/10.1177/0950422219901102

[18] O. Sagy, Y. Hod, and Y. Kali, "Teaching and learning cultures in higher education: a mismatch in conceptions". Higher Education Research \& Development, vol. 38, issue 4, pp. 849- 863, Feb 2019. https://doi.org/10.1080/07294360.2019.1576594

[19] A. M. Spear, J. H. Y. Yau, K. W. K. Lo, and S. C. F. Chan, "Impact of service-learning pedagogy on students' Learning Outcomes" in Proc. of the 3rd Int. Conf. on Service Learning, 2019, pp. 84-88.

[20] Anuar et al. "Impact of Multi-Disciplinary International Engineering Service-Learning in Instilling Global Engineer Attributes among Undergraduates". ASEAN Journal of Engineering Education, vol. 3, no. 9, pp. 96-108, Dec 2019.

[21] J. Davis, E. Madden, C. Cronley, and K. Beamon, "Voices from the Field: A Qualitative Exploration of Community Partners" Definitions of Service-Learning. Partnerships: A Journal of Service-Learning and Civic Engagement, vol.10, no.1, pp. 146-155, 2019.

[22] R. G. Bringle, and P. H. Clayton, "Integrating Service Learning and Digital Technologies: Examining the Challenge and the Promise".RIED. Revista Iberoamericana de Educación a Distancia, vol 23, no.1, pp. 43-65, 2020. https://doi.org/10.5944/ried.23.1.25386

[23] A. Yusof, N. A. Atan, J. Harun, and M. Doulatabadi, "Developing students graduate attributes in service learning project through online platform". in Proc. of the International Conference on Industrial Engineering and Operations Management Bangkok, 2019.

[24] A. Jenkins, and P. Sheehey, "A checklist for implementing service-learning in higher education". Journal of Community Engagement and Scholarship, vol 4, no. 2, pp. 52-60, Aug 2011.

[25] J. Rocheleau, "Theoretical roots of service-learning: Progressive education and the development of citizenship". in Service-learning: History, theory, and issues, B. W. Speck, S. L. Hoppe, 2004, pp. 3-21.

[26] S. B. Rinaldo, D. F. Davis, and J. Borunda, "Delivering value to community partners in service-learning projects". Journal of Community Engagement and Scholarship, vol 8, no1, pp. 115-124, Jan 2015.

[27] B. J. Muhlestein, and R. McCann, “Assessing Community-Engaged Learning Impacts using Ripple Effects Mapping”. Journal on Empowering Teaching Excellence, vol 3, issue 2, article 5, pp 32-53, Dec 2019.

[28] J. Hoxmeier, and M. M. Lenk, "Service-learning in information systems courses: Community projects that make a difference". Journal of Information Systems Education, vol 14, issue 1, pp. 91-100, 2020.

[29] K. Singh, "Report of the Special Rapporteur on the right to education" United Nations Human Rights Council. New York, USA, 2016.

[30] J. Saltmarsh, "Ethics, Reflection, Purpose, and Compassion: Community Service Learning", 
[31] New Directions for Student Services, no.77, pp. 81-93, 1997.

[32] D. Budny, L. Lund, and R. Khanna, "Designing Service Learning Projects for Freshman Engineering Students". International Journal of Engineering Pedagogy, vol 3, pp. 31-38. Feb 2013. https://doi.org/10.3991/ijep.v3is1.2371

[33] A Manifesto for Global Engineering Education, Summary Report of the Engineering Futures Conference, January 22-23, 1997. The Boeing Company \& Rensselaer Polytechnic Institute

[34] S. Hundley, and L. G. Brown, The Attributes of a Global Engineer Project: Updates, Inputs, Faculty Development Considerations. ASEE International Forum. 2013. https://doi.org/10.18260/1-2--17269

[35] A. D. C Chan, \& J. Fishbein, "A global engineer for the global community". The Journal of Policy Engagement, vol1, no. 2, pp 4-9, 2009.

[36] G. A Bowen, "Document analysis as a qualitative research method". Qualitative Research Journal, vol 9, no. 2, pp 27-40, 2009.

[37] Khairiyah Mohd-Yusof, F. A. Phang, Aziatul Niza Sadikin and Syed Ahmad Helmi, Determining the Effect of an Engineering Overview Assignment on Students.in Proceedings for the 2014 ASEE Annual Conference and Exposition on Engineering Education, Indianapolis, USA, 2014. https://doi.org/10.18260/1-2--20273

[38] M. B. Miles, \& A. M. Huberman, Qualitative data analysis: An expanded sourcebook, 2nd ed. Sage Publications, 1994.

[39] E. Dale, Audiovisual Methods in Teaching, NY: Dryden Press, 1969.

[40] F. Mirzaei, F. A. Phang, Seth Sulaiman, H. Kashefi, \& Zaleha Ismail, Mastery Goals, Performance Goals, Students' Beliefs and Academic Success: Metacognition as a Mediator. Procedia - Social and Behavioral Sciences,vol 46, pp. 3603-3608 , 2012. https://doi.org/ $\underline{10.1016 / j . s b s p r o .2012 .06 .113}$

[41] V. B. Marcus, N. A. Atan, S. M. Yusof, \& U. Mastura, "Students' perception towards engaging factors of extreme e-service learning design for computer network course". International Journal of Interactive Mobile Technologies, vol 15, issue 5, pp. 100-115, 2021. https://doi.org/10.3991/ijim.v15i05.20901

[42] V. B. Marcus, N. A. Atan, R.Talib, A. A. Latif, and S. M. Yusof, "Promoting students' generic skills with the integration of e-service learning platform". International Journal of Emerging Technologies in Learning, vol14, issue 20, pp. 4-17, 2019. https://doi.org/10.3991 lijet.v14i20.11455

\section{Authors}

Fatin Aliah Phang is a Professor at the School of Education, Faculty of Social Sciences and Humanities, Universiti Teknologi Malaysia (UTM) and also a research fellow at the Centre for Engineering Education, UTM. She is an expert in STEM education and environmental education.

Jaysuman Bin Pusppanathan received his Ph.D. degree from UTM in 2016. He is currently a Senior Lecturer in the School of Biomedical Engineering \& Health Sciences, Faculty of Engineering, UTM. He is also a research follow for Sports Innovation \& Technology Centre (SiTC). His current research interests are electrical tomography for both process industry and biomedical applications, sensors and drone technology.

Nina Diana Nawi is a senior lecturer at the School of Education, Faculty of Social Sciences and Humanities, UTM. Her research interests are in STEM education, Problem based-Learning and Low Carbon Education. 
Nur Amira Zulkiflli is currently pursuing her Ph.D. degree in UTM, where she also received her M. Eng in Electrical Engineering there in 2018. Her research interest includes sensor technology and tomographic imaging.

Izwyn Zulkapri is a senior lecturer at the School of Biomedical Engineering and Health Sciences, Faculty of Engineering, UTM and also an associate member at the Sports Innovation and Technology Centre, UTM. Her research interests include sports science and technology, sports testing and performance, as well as health and wellness.

Fauzan Khairi Che Harun is a senior lecturer at the Faculty of Electrical Engineering, UTM. His research interests are mainly biomedical electronics, Biological Inspired Micro-system and Electronic Nose System.

Adam Wong Yoon Khang is a senior lecturer Universiti Teknikal Malaysia Melaka (UTeM). He is a research member at Center for Telecommunication Research and Innovation. His research interest is Internet of Things, Hybrid Optical Wireless and simulation optimization.

Jamil Abedalrahim Jamil Alsayaydeh Jamil is a senior lecturer UTeM. His research interests include formal methods, simulation, Automatic Control of Process, computer system and networks, real time system and internet of things

Tee Kian Sek is a senior lecturer at Universiti of Tun Hussein Onn Malaysia (UTHM). His research interest includes mechatronics, rehabilitation system, gait monitoring system, exo-skeleton and robotics.

Article submitted 2021-05-01. Resubmitted 2021-06-11. Final acceptance 2021-06-12. Final version published as submitted by the authors. 